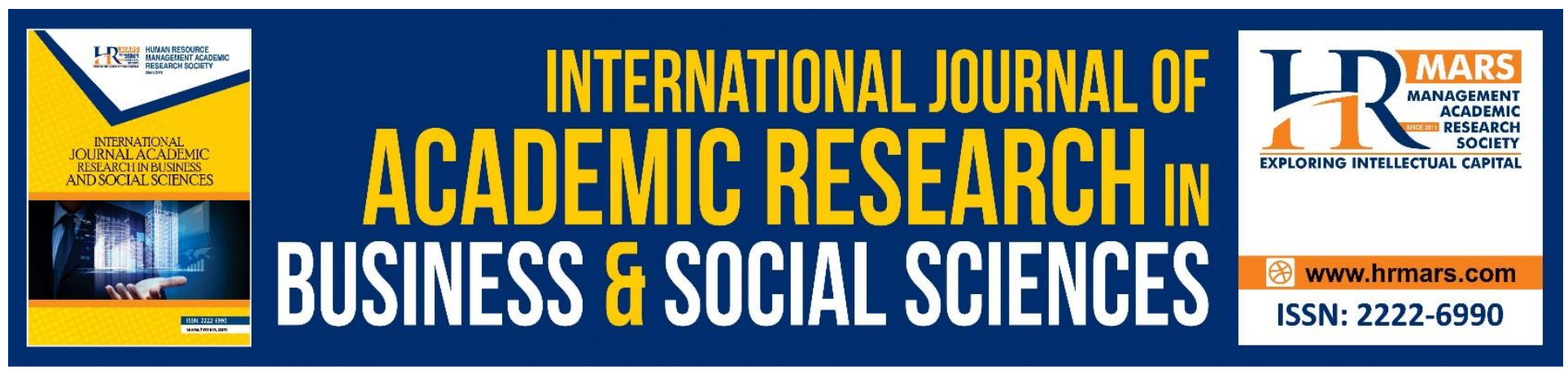

\title{
Thought Leadership in the Education Industry: A Review
}

\section{Ong Choon Hee and Kumutha Vimalathithan}

To Link this Article: http://dx.doi.org/10.6007/IJARBSS/v9-i4/5809

DOI: $10.6007 /$ IJARBSS/v9-i4/5809

Received: 27 Feb 2019, Revised: 10 March 2019, Accepted: 26 March 2019

Published Online: 03 April 2019

In-Text Citation: (Hee \& Vimalathithan, 2019)

To Cite this Article: Hee, O. C., \& Vimalathithan, K. (2019). Thought Leadership in the Education Industry: A Review. International Journal of Academic Research Business and Social Sciences, 9(4), 1-7.

Copyright: @ 2019 The Author(s)

Published by Human Resource Management Academic Research Society (www.hrmars.com)

This article is published under the Creative Commons Attribution (CC BY 4.0) license. Anyone may reproduce, distribute, translate and create derivative works of this article (for both commercial and non-commercial purposes), subject to full attribution to the original publication and authors. The full terms of this license may be seen

at: http://creativecommons.org/licences/by/4.0/legalcode

Vol. 9, No. 4, 2019, Pg. 1 - 7

http://hrmars.com/index.php/pages/detail/IJARBSS

JOURNAL HOMEPAGE

Full Terms \& Conditions of access and use can be found at http://hrmars.com/index.php/pages/detail/publication-ethics 


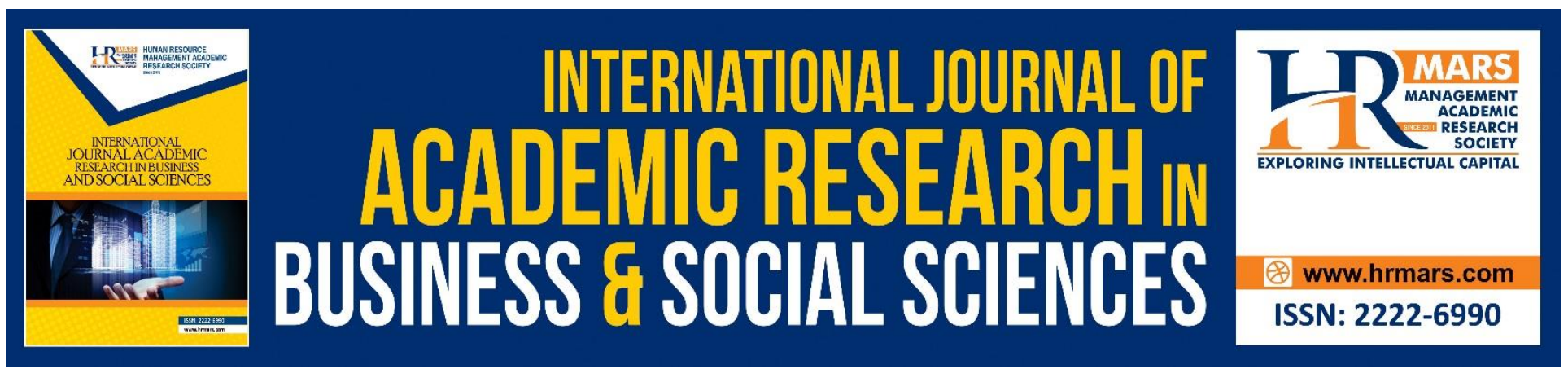

\title{
Thought Leadership in the Education Industry: A Review
}

\author{
Ong Choon Hee and Kumutha Vimalathithan \\ Azman Hashim International Business School, Universiti Teknologi Malaysia, Johor, Malaysia. \\ Corresponding Author: ongchoonhee@gmail.com
}

\begin{abstract}
Today, we are moving forward at the beginning of a fourth Industrial Revolution (IR4.0). IR 4.0 had given a new momentum to the educational transformation of future generation. This revolution will make our lives move faster and easier in the coming years. Thought leaders are those who give opinions to their followers in their field of expertise. They influence people in education industry by creative and innovative ideas which turn into reality of the future world. Thought leaders know how to be successful and productive in their field. They build a dedicated group of people to help them achieving the goals powered by artificial intelligence, 3D simulators, virtual world and remote experiments. It will be very different and unique from the environment of today. Thought leaders will give a big impact to the education sector and future perspectives for teaching and learning for early childhood education until universities. Students will enter new competencies, new structures, new learning styles and new mental models. These new technology changes in IR 4.0 will eliminate several of the existing jobs and create new job opportunities. Our regular activities and jobs will be taken by robots and machines. In this case, it is essential to create appropriate education system by thought leaders in the future workforce. The world is changing but what thought leaders need to do is to implement changes that are needed to fit our young people towards the fourth industrial age.
\end{abstract}

Keywords: Thought Leadership, Education Industry, Industry Revolution 4.0.

\section{Concepts and Definition of Thought Leadership}

Defined as a radical departure from traditional leadership, thought leadership is the championing of new ideas rather than anything to do with managing people or helping a group to achieve a goal. (McCrimmon, 2005). Thought leaders inspire leadership; ignite imagination, explode old myths, and illuminate paths to the future that others can follow (Butler, 2012). It is very important to draw a distinction between thought leadership and traditional leadership. The latter mandates authority over others and can vary in leadership styles which include charismatic, altruistic, transformational, and commanding leadership. Some forms of traditional leadership are indispensable regardless of the organizational structure. On the other hand, thought leadership does not require management 
of other people and is particularly vital where innovation is essential to the success of the organization (McCrimmon, 2005). Therefore, thought leadership can be an integral part of an organizational structure that is focused on innovation. To be successful in the future, students will need to have the right digital education in the schools and universities. Digital transformation that is making of IT skills is very important. Digital industry will providing new opportunities for digital learning. All sectors have to be prepared for facing the challenges of digitalization in the present. Digital education only can be succeeded if thought leadership is nurtured among well qualified teachers or lecturers to achieve necessary goals. Primary and secondary schools have big roles and responsibilities in providing necessary digital education to the students. In order to make digital education to become a reality, digital qualified teachers and lecturers should be modernized as well. It requires thought leadership quality among the teachers. This is owing to only the well qualified teachers can convey relevant information of digital education to the students. The future education system will emphasize on innovation, technology, digital, science and mathematics. Thought leaders in the education industry play important roles in putting the efforts to be practical and providing digital learning classroom. Education 4.0 is a big challenge in developing individual to think creatively and innovatively in order to adapt the changes. Students will find themselves where they want to be in their future career that may not exist now.

\section{Thought Leadership and Traditional Leadership}

The distinction between thought leadership and traditional leadership is that anybody can become a leader without being a thought leader. Traditional leadership is indispensable regardless of the organizational structure. On the other hand, thought leadership may not require the management of people and is particularly vital where innovation is essential to the success of the organization. Thought leadership is the promotion of new ideas; an initiative rather than a position or role. Thought leadership qualities can be exhibited by non-managerial employees with revolutionary mind-sets and the capabilities of championing new ideas. Moreover, thought leadership is egalitarian and nonhierarchical, and is not easily monopolized. Unlike traditional leadership that exists permanently in the organization, thought leadership starts with the spark of a new idea and ends with the implementation of the idea. A thought leader continues to champion other news ideas until the end of implementation phase.

\section{Thought Leadership in the Education Industry}

Thought leaders play important roles in Implementing Industry 4.0 as it has huge challenges in terms of employment, security, privacy and capital. In Education 4.0, different methods of education delivery need to be implemented by thought leaders like digital technology. Thought leaders need to implement different solutions in the education sector in solving problems faced by the students especially in information technology and security risk. Implementing Industry 4.0 might not guarantee privacy and security in the future. Digital technology provides numerous benefits to us but it is prone to create digital crimes. Such changes in digital transformation require huge capital investment that does not sound cheap. In addition, this transformation needs high cost in managing the education system. Hence, thought leaders in the education industry should prepare our students to face Industry 4.0 and at the school and university level. This is to make sure that every student is 
carefully monitored in terms of acquiring digital technology knowledge according to their needs. Thought leaders in the education management are crucial in facilitating and providing efficiency, transparency and satisfaction in digital education. Thought leadership that emphasizes on future teaching and learning must turn challenges into opportunities for change. As for the education of our future generation, recognizing that the emergence of Gen Z preferences and wants towards Industry 4.0, the curriculum content definitely have to be upgraded to educate the students about the nature and benefits of Industry 4.0. In doing so, students will aware and get prepared to enter the most anticipating workforce impacted by Industry 4.0. For example, the Internet of Things (IoT) was totally changed the way most of us go through our daily tasks likes internet banking, online shopping, and e-learning. In the future intelligent devices in our house and office will respond to our request and fulfil our needs and wants. In order to adapt changes in the future, thought leaders are vitally important in developing a new education structure. The advancement of technologies consistently changes and transforms the existing teaching method and learning process in the classroom. In education 4.0, students will get great opportunities to learn anytime and anywhere as they wish. They will get interactive learning in the classroom as well as outside the classroom. E-learning will serve as a platform for self-placed learning. Students will promote positive learning by their own academic ability. However, Gen Z's learning preference maybe different from the previous generations who preferred to present physically and having hands-on experience in the learning process. Gen Z students will be fully engaged in the dramatic changes of Education 4.0. They demand for attractive and interactive learning environment with high technology and digital tools in the classroom.

\section{Implementing Thought Leadership}

In the digital era, faculty and non-faculty staffs in the education Industry 4.0 can become thought leaders. Thought leaders in the education industry need to expose their expertise in that particular industry to build reputation and open the eyes of others to get benefit from the added values. Thought leaders play important role in finding ways to achieve the goal. Firstly, Thought leaders should set a goal and educate others. They should ask themselves why they want to be a thought leader. What is the purpose to become a thought leader? Is it about making changes to achieve industrial revolution 4.0? Thought leaders should be willing to share their expertise with their followers and let others gain knowledge from the experiences. Secondly, to be a thought leader personal responsibilities are very important. They should describe their responsibilities to the followers so that the followers know what they do. They should identify their goal, vision, mission, passion, expertise and other facts that bring individuals towards achieving a new milestone. They build strong foundation in their expertise to assist in growing the education industry. Thirdly, thought leaders need to invest time in identifying values and examining required behaviors in building credibility. In order to bring virtual learning methods into the future world, they must provide ways to achieve that. Willingness and openness to share ideas and opinions with others and always finding realistic solutions to solve problems. Next, being a resourceful person, thought leader expands his or her knowledge and ideas to their followers. Digital transformation has impacted almost every industry especially in the educational sector. All level of students and educators will get to realize the benefits of technology in education. Education is essential for making drastic changes to begin in 
digital transformation and educational technology. Teachers and lecturers play the roles of thought leader in developing curriculum that can lead to higher order thinking among the students in terms of ethics, spirituality, leadership skills, national identity, language proficiency and critical thinking skills. Besides delivering higher education, thought leaders need to move towards creating classroom 4.0. Lack of digital culture and training is the biggest challenge to achieve classroom 4.0. Generally, students are expected to sit quietly in the classroom during lesson. Educational change in this situation needs collaborative and interactive efforts via educational technology. For example, virtual reality brings the outside world into the classroom. The classroom was occupied with sets of devices and no longer using the traditional learning methods. The classrooms look like a workforce room to create new student learning environment. Classrooms are equipped with SMART boards instead of using chalkboards and students will have SMART desks. They are creating ideas instead of just reading it from the text. They use SMART classrooms to design technology and work towards achieving specific goals. Besides, universities are using new platforms for collaborative and interactive lessons. They use artificial intelligence in the higher education to guide and facilitate students. Artificial Intelligence is able to guide students in tutorial and homework. It lessens the workload of teachers who usually conduct tutorials with the students. The Intelligent tutorials aim to replace instructors to produce high quality curriculum. Personalized learning give more responsibilities to the students to involve directly in the process of learning. Learning through videos, gamification, flashcards, and interactive learning would most likely to boost students' engagement and interest. Every student is expected to perform differently and with different order of skills in creating ideas. Education 4.0 maximizes learning into simulation learning method. Gamification makes students to learn difficult subject with more exciting and interactive way in the classroom. Virtual games create unique opportunity to the world to identify problems and solutions in various perspectives. The games are design to provide immediate response to the students in generating ideas and solutions throughout the learning process. New technologies design a unique way of learning and spark unthinkable possibilities among the students. If students' expectation in the future education increases dramatically, thought leaders in the education industry should be equally responsive to fulfil the students' needs.

\section{Common mistakes that should be avoided}

The Industrial 4.0 Revolution raises some ethical issues about the kind of world we want to live in the future. These new technologies hold powers and affect quality of human life in many ways. As we step into the new technology era, we need a new set of codified morals to become the global norm. If we do not prepare the necessary codified morals in advance, we might face several risks in the future. Human are great and intelligent in creating artificial intelligence and now it is a challenge for us to create laws that protect our own society. This is a responsibility for thought leaders to make specific rules to protect human rights. As we know the increasing use of digital technologies in classroom may create ethical issues that arise from the technology itself. Finding those ethical issues will assist us to better understand how to address them in the future. The society pushes students into the digital world to educate them without emotionally and mentally prepared for these changes. The new digital technology in the classroom can be extremely disruptive. Therefore, thought leaders are to ensure issues regarding cyberbullying, unauthorized access, safety and privacy were 
addressed. The amazing digital technology brings ethical consequences that all of us may not aware of it. We are living in the world that our movement can be tracked and traced anytime and our personal information is at risk of unauthorized disclosure. We should aware that digital technologies can lead to negative consequences if we never think about how technology can change us in return. More importantly, thought leaders have to start from now to ensure programming tools, artificial intelligence and robotic programs are under controlled and will not bring undesired outcomes in the education industry.

\section{Conclusion}

Industrial Revolution 4.0 has given a new momentum to educational transformation. It is believed that in the upcoming years, thought leaders in the education industry will find new solutions for future generation to thrive in this transformation world. Our future generation will be trained by thought leaders to produce innovative ideas, critical thinking skills to meet the changing demands. Our entire educational system will have new changes in the future as well. So, the new education system that based on digital transformation needs thought leaders to establish it in the future. Thought leaders will lead students to adapt the workforce culture during their studies as IR 4.0 requires both students and teachers to be innovative and entrepreneurial in dealing with complexity. Thought leaders in Education 4.0 are facing fundamental challenges in producing knowledgeable workforce with creativity and independent of judgment. In order to achieve the goal, thought leaders need to guide their followers to continuously learning, experiencing, searching and changing. As the world is moving fast, it requires professionals who can adapt to the situation and able to cope with the pace and keep upgrading their knowledge on daily basis. Everyone has to get ready for the Industrial Revolution because we will face a range of new technologies that combined with physical, digital and the biological world. Technologies have great potential to connect people around the world. It drastically improves the efficiency of education and business. Thought leaders in the education industry will have to influence the government, educators, parents and future generation to ensure continuous improvement in the teaching and learning context. Of course, the future education system must fully focus on outcomes-based curricular and programmes. Since the fourth industrial revolution has begun, thought leaders in the education sector are responsible to reshape the education system to fulfil future demands and acquire necessary skills and technologies to survive in the rapid changing world. Students in the new era should be able to interact across the globe and they need to be literally educated. Change will not wait for us and thought leaders must assist all educators and the government to be proactive in upskilling and retraining everyone to face the challenges ahead.

\section{Acknowledgements}

The authors would like to thank the Malaysian Ministry of Higher Education and Universiti Teknologi Malaysia (GUP-Vot: 14J81) for providing financial support to publish this paper. 
INTERNATIONAL JOURNAL OF ACADEMIC RESEARCH IN BUSINESS AND SOCIAL SCIENCES

Vol. 9, No. 4, April, 2019, E-ISSN: 2222-6990 (C) 2019 HRMARS

\section{References}

Butler, G. (2012). Think write grow. How to become a thought leader and build your business. Australia: John Wiley \& Sons.

Brown-Martin, G. (2017). Education and the Fourth Industrial Revolution Prepared for Groupe Média TFO, (August).

Jeschke, S., \& Heinze, U. (2014). Higher Education 4.0-Trends and Future Perspectives for Teaching and Learning Responsive Open Learning Environments View project, (March). https://doi.org/10.13140/RG.2.1.1509.0002

McCrimmon, M. (2005). Thought leadership: a radical departure from traditional, positional leadership. Management Decision.

Penprase, B. E. (2018). Higher Education in the Era of the Fourth Industrial Revolution, 207-229. https://doi.org/10.1007/978-981-13-0194-0

Selamat, A. (2017). Higher Education 4.0: Current Status and Readiness in Meeting the Fourth Industrial Revolution Challenges. Our Team Members: Datin Paduka Ir. Dr. Siti Hamisah Tapsir, Assoc. Prof. Dr Marlia Puteh, Prof. Dr Rose Alinda Alias (August).

Summit, M., Moavenzadeh, J., \& Forum, W. E. (2015). The 4th Industrial Revolution : Reshaping the Future of Production "The Future of Production": A Caveat.

World Economic Forum. (2016). The Future of Jobs Employment, Skills and World Economic Forum. The Future of Jobs Employment, Skills and Workforce Strategy for the Fourth Industrial Revolution. Growth Strategies, (January), 2-3. http://doi.org/10.1177/1946756712473437

World Economic Forum, \& Asian Development Bank. (2017). ASEAN 4.0: What does the Fourth Industrial Revolution mean for regional economic integration? World Economic Forum, (November), 18. https://doi.org/http://dx.doi.org/10.22617/TCS179126-2 